\title{
EFFECT OF PLANTING DENSITY ON THE PERFORMANCE OF BORO RICE (BRRI dhan28)
}

\author{
A. M. Mahmud 1 , M. Y. Ali ${ }^{2}$, K. G. Quddus ${ }^{3}$ and S. Parvin ${ }^{4}$ \\ ${ }^{1}$ Development Professional, 2 \& 3Professor, Agrotechnology Discipline, Khulna University \\ ${ }^{4}$ Lecturer, Govt. Bangabandhu College, Khulna \\ Corresponding author: ammahmud2005@gmail.com
}

Key words: Boro rice, planting method, paired row, single row, row arrangement, yield

\begin{abstract}
A field experiment was conducted at the Agrotechnology Field Laboratory of Khulna University during the boro season to evaluate the effect of planting density on the performance of rice variety BRRI dhan28. The experiment received twelve treatments, which were divided into two distinct patterns - single row and paired row. The single row had four treatments and paired row had eight treatments. Planting densities were 40, 27, 20 and 16 hills $\mathrm{m}^{-2}$. The experiment was arranged in a randomized complete block design (RCBD) with three replications. Standard management practices were followed in raising crops. Results revealed that closer spacing produced higher yields where 40 hills $\mathrm{m}^{-2}$ produced the most $\left(4.81 \mathrm{t} \mathrm{ha}^{-1}\right)$, which was statistically similar with that of 27 hills $\mathrm{m}^{-2}$. Paired row planting showed better performance than single row planting. Plant height, grains panicle ${ }^{-1}$, sterile spikelets panicle ${ }^{-1}, 1000$-grain weight, grain yield were found better in paired row planting. Paired row planting at a spacing of $(35 \mathrm{~cm}+15 \mathrm{~cm})$ $\times 10 \mathrm{~cm}$ i.e row to row distance is $35 \mathrm{~cm} \& 15 \mathrm{~cm}$ and hill to hill distance is $10 \mathrm{~cm}$; found the highest grain yield $\left(4.81 \mathrm{tha}^{-1}\right)$ and the lowest yield $\left(2.97 \mathrm{tha}^{-1}\right)$ was found in single row using a spacing of $25 \mathrm{~cm} \times 25 \mathrm{~cm}$.
\end{abstract}

\section{Introduction}

Rice is the most important cereal crop in the world. It is the staple food for about $50 \%$ of the world's population. Bangladesh is the fourth largest producer and consumer of rice in the world with an annual production ranging from 17 to 20 million tons. Rice occupies $70.66 \%$ of total cropped area in which boro rice is cultivated in 47.60 lakh ha area in 2012-13. The average total production of rice in Bangladesh is 187.78 lakh $\mathrm{m}$ ton (AIS, 2014). Compared with midsixties, Bangladesh has almost doubled its production during the past three decades and the growth in production came mainly from reallocation of land from traditional to high yielding modern varieties (HYVs). Modern varieties at present cover $92.3 \%$ of boro, $31.4 \%$ of aus and $51 \%$ of transplanted aman rice area (Miah and Hamid, 1999) and Bangladesh has attained nearly self-sufficiency in food. A modest estimate (Zaman, 1996) suggests that to feed the growing population, the demand for rice in Bangladesh would have to be increased by over $80 \%$ even in the next 20 years. To produce the required quantity of additional food, yield must be increased through increasing that per area.

To meet this challenge rice scientists have been working to develop new techniques Among them, desired number of plant population per unit area has profound influence on grain yield of rice (Islam, 1986). The plant density influences leaf area index, crop growth rate, net assimilation rate, specific leaf area, photosynthesis, respiration and ultimately yield. Optimum planting density enables the rice plant to grow properly both in its aerial and underground parts by utilizing maximum radiant energy, space and water which ultimately leads to boost crop production (Miah 
et al., 1990). In densely populated rice fields the intra - specific competition between the plants is high which sometimes results in lower grain yield. On the contrary, sparsely populated fields with wide spacing lead to uneconomic utilization of space, profuse growth of weeds and pests and reduction of grain yield unit area $^{-1}$.

There had been several studies on the yield - density relationship (Willey and Heath, 1969) using a wide variety of crops, but the concept of optimum population density for maximum yield has not yet been figured out (Duncan, 1986). In contrast to the earlier proposition that closer spacing increases intra - specific competition and affects grain yield (BRRI, 1990) and quality (Karim et al., 1992). Several studies revealed that closer spacing increases grain yield (Islam et al., 1994). However, there is a third school of thought which advocated that grain yield is unaffected by plant density (Balsubramaniyan and Palaniappan, 1991). A number of reports (Counce et al., 1989) also indicated a curvilinear relationship between plant population density and rice grain yield. Under transplanted condition, grain yield plateau has been found to reach with 25 to 200 plants $\mathrm{m}^{-2}$ (Akita, 1982). Works conducted at BRRI (Anonymous, 1992) suggested that within a range of 16 to 67 plant $\mathrm{m}^{-2}$, grain yield increased with the increase of plant density irrespective of varieties.

Each variety has certain tiller producing capacity and adequate number of effective tillers per unit area that exerts a role in producing panicles and spikelets and ultimately grain yield (Miller et al., 1991). Optimum number of tillers per unit area is a prerequisite for obtaining maximum yield that increases with increased number of panicles per unit area (BRRI, 1995). Higher yield potential of hybrid rice is primarily attributed to profused tillering, large number of panicles and higher spikelet density. It is assumed that BRRIdhan28 may also yield higher if higher number of panicles per unit area with more or equivalent of 100 filled spikelets per panicles are ensured.

Under the above circumstances, it was felt necessary to examine the effect of planting density on the performance of BRRI dhan28 with the objectives of observing the growth and yield performance of BRRI dhan-28 rice at a range of different population densities, and finding out the optimum population density and planting configuration of rice variety BRRI dhan-28 for better growth and higher yield.

\section{Materials and Methods}

A field experiment was conducted at the Agrotechnology Field Laboratory of Khulna University, Khulna during the boro season of 2005. The soil was characterized by silty loam texture having $\mathrm{p}^{\mathrm{H}}$ value of 5.6. The experiment was comprised of twelve treatments which were divided into two distinct pattern - single row and paired row. The single row had four treatments : $25 \mathrm{~cm} \times$ $10 \mathrm{~cm}\left(40\right.$ hills $\left.\mathrm{m}^{-2}\right), 25 \mathrm{~cm} \times 15 \mathrm{~cm}\left(27\right.$ hills $\left.\mathrm{m}^{-2}\right), 25 \mathrm{~cm} \times 20 \mathrm{~cm}\left(20\right.$ hills $\left.^{-2}\right) \& 25 \mathrm{~cm} \times 25$ $\mathrm{cm}\left(16\right.$ hills $\left.\mathrm{m}^{-2}\right)$ and Paired row had eight treatments: $(35 \mathrm{~cm}+15 \mathrm{~cm}) \times 10 \mathrm{~cm}\left(40 \mathrm{hills} \mathrm{m}^{-2}\right)$, $(35 \mathrm{~cm}+15 \mathrm{~cm}) \times 15 \mathrm{~cm}\left(27\right.$ hills $\left.\mathrm{m}^{-2}\right),(35 \mathrm{~cm}+15 \mathrm{~cm}) \times 20 \mathrm{~cm}\left(20\right.$ hills $\left.\mathrm{m}^{-2}\right),(35 \mathrm{~cm}+15$ $\mathrm{cm}) \times 25 \mathrm{~cm}\left(16\right.$ hills $\left.\mathrm{m}^{-2}\right),(30 \mathrm{~cm}+20 \mathrm{~cm}) \times 10 \mathrm{~cm}\left(40\right.$ hills $\left.\mathrm{m}^{-2}\right),(30 \mathrm{~cm}+20 \mathrm{~cm}) \times 15 \mathrm{~cm}$ $\left(27\right.$ hills $\left.\mathrm{m}^{-2}\right),(30 \mathrm{~cm}+20 \mathrm{~cm}) \times 20 \mathrm{~cm}\left(20\right.$ hills $\left.\mathrm{m}^{-2}\right) \&(30 \mathrm{~cm}+20 \mathrm{~cm}) \times 25 \mathrm{~cm}\left(16 \mathrm{hills} \mathrm{m}^{-2}\right)$. The experiment was laid out in a Randomized Complete Block Design (RCBD) with 3 replications. The unit plot size was $4.0 \mathrm{~m} \times 2.5 \mathrm{~m}$. Plot to plot distance was $0.75 \mathrm{~m}$ and block to block distance was $1 \mathrm{~m}$. The seedlings of rice variety BRRIdhan28 were hand transplanted at the age of 40 days, transplanting two seedlings in each hill. Row to row and hill to hill distance were maintained according to the treatment. The experimental plots were fertilized with 80, 50, 40, 10 and $5 \mathrm{~kg} \mathrm{ha}^{-1}$ of $\mathrm{N}, \mathrm{P}, \mathrm{K}, \mathrm{S}$ and $\mathrm{Zn}$, respectively. One third dose of urea and full dose of other fertilizers were applied as basal at the time of final land preparation and thoroughly incorporated 
Planting Density effects on Boro Rice

into the soil. The remaining two third of urea was top dressed in two equal installments, at panicle initiation stage and another at active tillering stage. Growth parameters of the experiment was studied considering plant height, number of tillers, dry matter accumulation \& crop growth rate and yield \& yield contributing characters were studied considering plant height, number of tillers \& panicles, length of panicle, grain number per panicle, 1000-grain weight, grain yield, straw yield, biological yield and harvest index. The crops were harvested at full maturity when $90 \%$ of the seeds turned golden yellow in color. The grain and straw yield were adjusted to $14 \%$ moisture level. Quantitative data were subjected to Analysis of Variance (ANOVA) and means of the treatments were compared using Duncan's Multiple Range Test (DMRT) (Gomez and Gomez, 1984).

\section{Results and Discussion}

Plant height increased progressively reaching maximum or peak (Fig.1). Plant height increased almost exponentially up to 53 DAT (flowering) irrespective of treatments, thereafter it nearly reached a plateau. Variation in plant height was observed among the treatments. It was observed that wider spacing increased plant height which was obvious (Shah et al., 1991; Zadeh and Mirlohi, 1998). It was also seen that paired row planting performed well than single row planting. Planting pattern $(35 \mathrm{~cm}+15 \mathrm{~cm}) \times 25 \mathrm{~cm}$ having 16 hills $\mathrm{m}^{-2}$ showed higher height than that of $25 \mathrm{~cm} \times 20 \mathrm{~cm}\left(20\right.$ hills $\left.\mathrm{m}^{-2}\right)$.

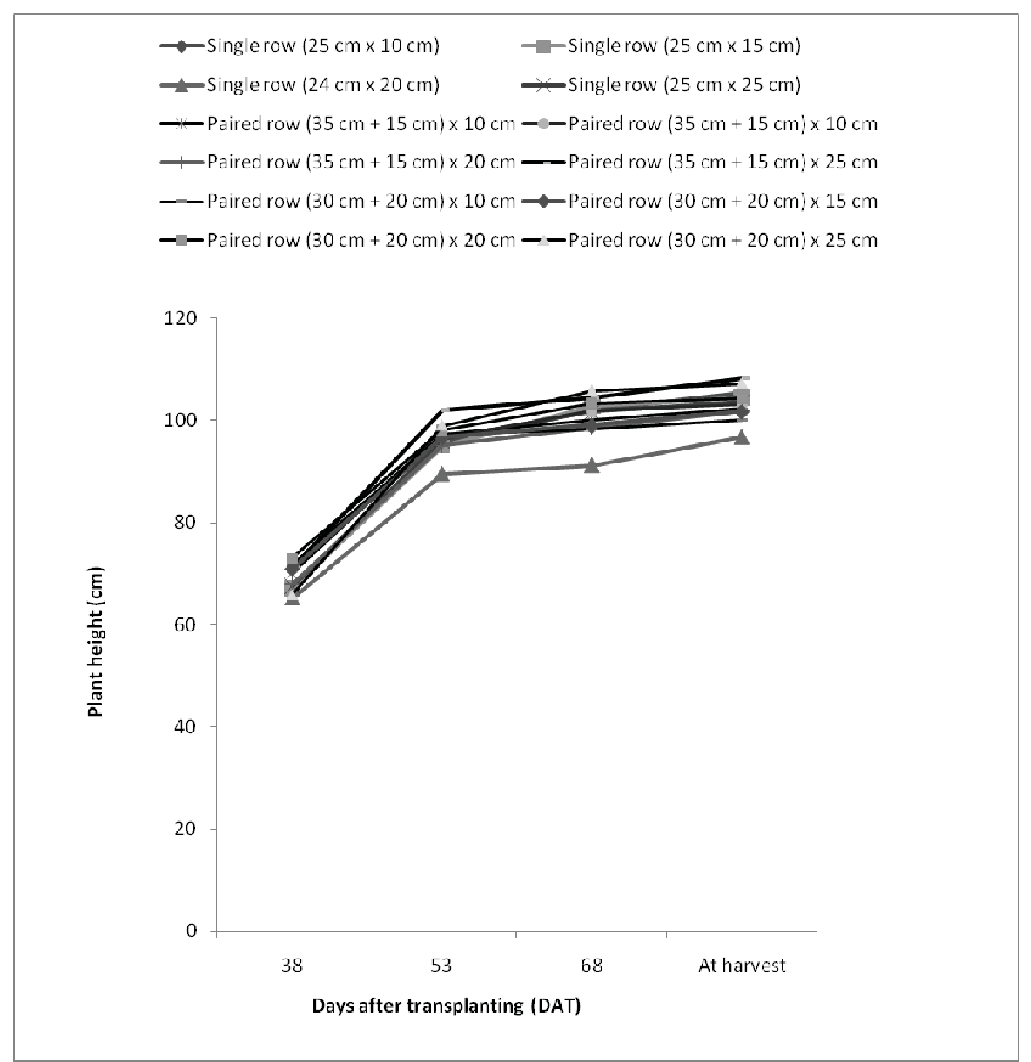

Fig. 1. Plant height over time as affected by planting density 
Mahmud et al.

The highest plant height $(108.1 \mathrm{~cm})$ at maturity was found in a paired row planting with a spacing of $(35 \mathrm{~cm}+15 \mathrm{~cm}) \times 25 \mathrm{~cm}$ having 16 hills $\mathrm{m}^{-2}$ and the lowest plant height was found in single row planting of $25 \mathrm{~cm} \times 10 \mathrm{~cm}$ spacing ( 40 hills $\mathrm{m}^{-2}$ ).

Tiller production was affected markedly by planting density. Tiller number in all the treatments increased almost exponentially up to 53 DAT (Fig. 2) i.e. flowering time. It was shown that higher planting density produced higher number of tillers $\mathrm{m}^{-2}$. From 53 DAT onwards, a sharp decline in tiller number was noticed which again reached a plateau from 68 DAT and onwards. Number of tillers $\mathrm{m}^{-2}$ was found to be higher in single row than paired row. In single row pattern $25 \mathrm{~cm} \times 10 \mathrm{~cm}$ spacing showed higher tillers than that in paired row.

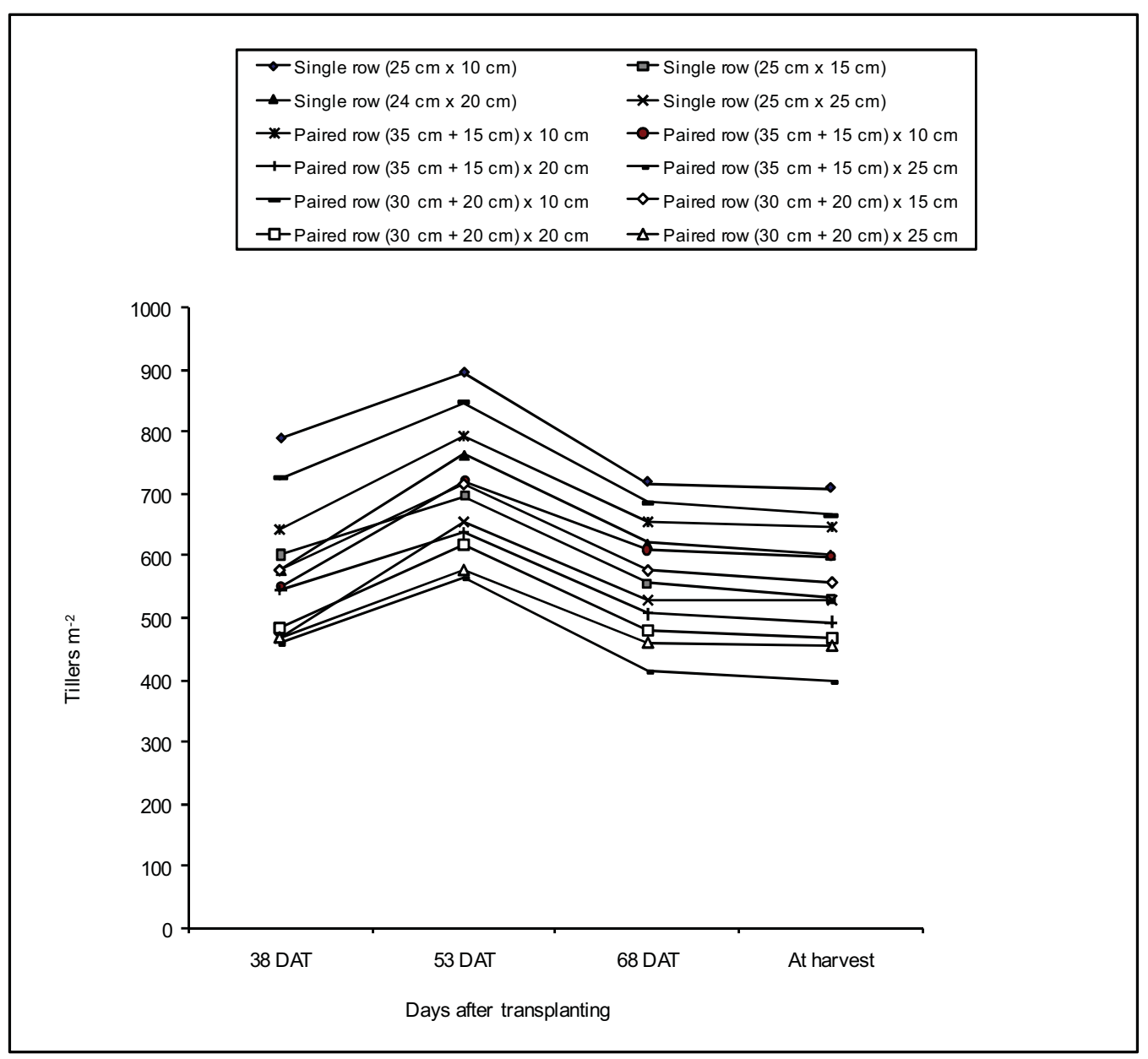

Fig. 2. Tiller dynamics over time as affected by planting density

The result agreed well with Hassan (1991). Miller et al. (1991) reported that the number of active tillers declined until reaching a constant tiller density by heading which was also apparent in the present study.

In the present study it was observed that the single row performed well than paired row. Planting pattern that includes 40 hills $\mathrm{m}^{-2}$ also performed well than 16 hills $\mathrm{m}^{-2}$ at maturity. The highest tillers $\mathrm{m}^{-2}$ was found in a single row planting with a spacing of $25 \mathrm{~cm} \times 10 \mathrm{~cm}$ having 40 hills 
Planting Density effects on Boro Rice

$\mathrm{m}^{-2}$ and the lowest tillers $\mathrm{m}^{-2}$ was found in paired row spacing of $(35 \mathrm{~cm}+15 \mathrm{~cm}) \times 25 \mathrm{~cm}$ having 16 hills $\mathrm{m}^{-2}$.

Dry matter (DM) accumulation was recorded at 15 days interval starting at 38 DAT (Fig. 3). It increased with increasing plant density and this phenomena was previously demonstrated by many workers (Talukder, 1998; Jahan, 1988; Roshid, 1998; Rahman, 1997). In paired row planting pattern, $(30 \mathrm{~cm}+20 \mathrm{~cm}) \times 10 \mathrm{~cm}$ showed higher values of dry matter till harvest.

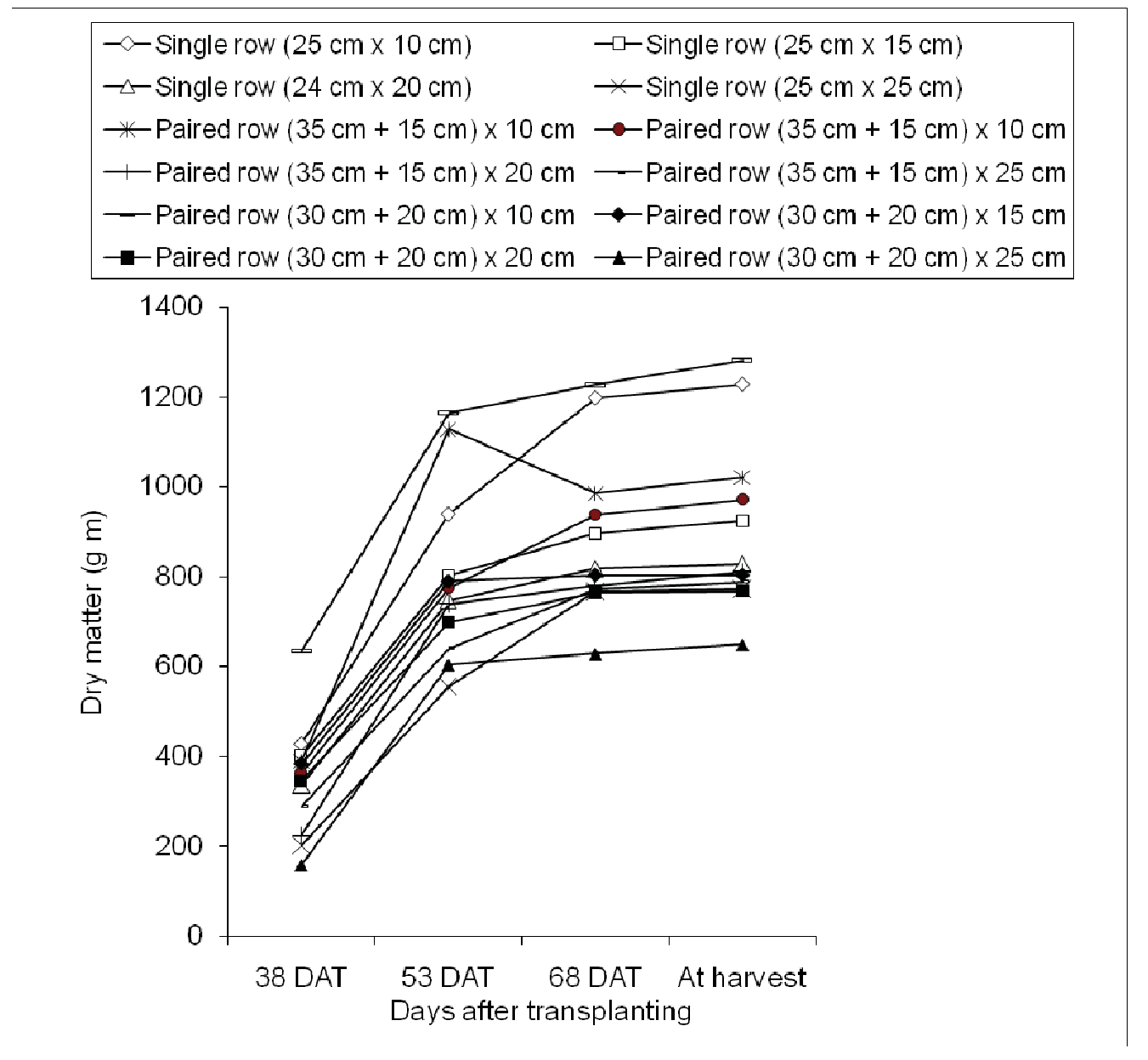

Fig. 3. Total dry matter production as affected by planting density

Increased plant density increased crop growth rate (CGR) during early stage which then gradually decreased and this result agree well with that of Miah and Hamid (1999).

The lowest panicles $\mathrm{m}^{-2}$ was found in paired row having 16 hills $\mathrm{m}^{-2}$ which increased up to planting density of 40 hills $\mathrm{m}^{-2}$ in single row. The highest (522.7) panicles $\mathrm{m}^{-2}$ was found in single row spacing $25 \mathrm{~cm} \times 25 \mathrm{~cm}$, and also found highest with $(35 \mathrm{~cm}+15 \mathrm{~cm}) \times 10 \mathrm{~cm},(30$ $\mathrm{cm}+20 \mathrm{~cm}) \times 10 \mathrm{~cm}$ spacing, respectively. The lowest (233.6) panicles $\mathrm{m}^{-2}$ was found in paired row spacing of $\times(30 \mathrm{~cm}+20 \mathrm{~cm}) \times 25 \mathrm{~cm}$ (Table 1$)$. 
Mahmud et al.

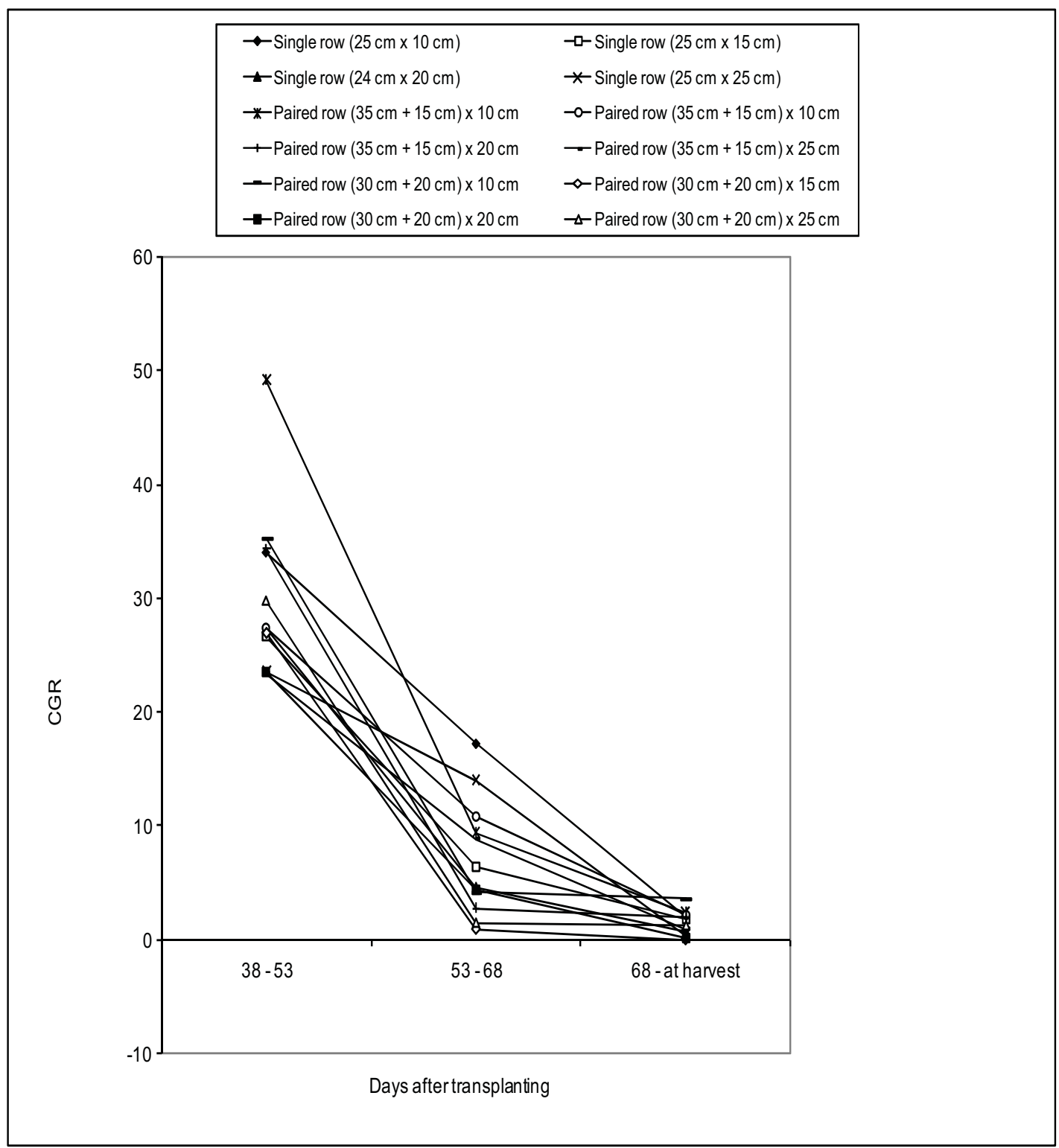

Fig. 4. Crop growth rate (CGR) as affected by planting density.

Single row planting showed longer panicle than double row and this was obvious as the single row planting had more population (Liou, 1987). 16 hills $\mathrm{m}^{-2}$ also showed longer panicles than 40 hills $\mathrm{m}^{-2}$. That is, higher panicle length $(24.33 \mathrm{~cm})$ was found in single row planting at a spacing of $25 \mathrm{~cm} \times 25 \mathrm{~cm}$ and the lowest panicle length $(21.80 \mathrm{~cm})$ founded in paired row planting at a spacing of $(35 \mathrm{~cm}+15 \mathrm{~cm}) \times 10 \mathrm{~cm}$. 
Planting Density effects on Boro Rice

Table 1. Planting density effects on plant characters, yield and yield attributes of rice variety BRRI dhan28

\begin{tabular}{l|c|c|c|c|c|c|c|c}
\hline Treatments & $\begin{array}{c}\text { Panicles } \\
\mathrm{m}^{-2}\end{array}$ & $\begin{array}{c}\text { Panicle } \\
\text { length } \\
(\mathrm{cm})\end{array}$ & $\begin{array}{c}\text { Grain } \\
\text { number } \\
\text { panicle }^{-1}\end{array}$ & $\begin{array}{c}\text { Sterile } \\
\text { spikelets } \\
\text { panicle }\end{array}$ & $\begin{array}{c}1000 \text {-grain } \\
\text { weight } \\
(\mathrm{g})\end{array}$ & $\begin{array}{c}\text { Grain } \\
\text { yield } \\
\left(\mathrm{t} \mathrm{ha} \mathrm{a}^{-1}\right)\end{array}$ & $\begin{array}{c}\text { Straw } \\
\text { yield } \\
(\mathrm{t} \mathrm{ha}-1)\end{array}$ & $\begin{array}{c}\text { Harvest } \\
\text { Index } \\
(\%)\end{array}$ \\
\hline $\mathrm{T}_{1}$ & $522.7 \mathrm{a}$ & $22.13 \mathrm{bc}$ & $225.1 \mathrm{j}$ & $88.0 \mathrm{e}$ & $19.84 \mathrm{c}$ & $4.24 \mathrm{ab}$ & $7.29 \mathrm{a}$ & 36.86 \\
$\mathrm{~T}_{2}$ & $416 \mathrm{a}-\mathrm{d}$ & $22.33 \mathrm{bc}$ & $255.9 \mathrm{~h}$ & $91.67 \mathrm{e}$ & $20.74 \mathrm{bc}$ & $4.03 \mathrm{abc}$ & $5.47 \mathrm{bc}$ & 42.62 \\
$\mathrm{~T}_{3}$ & $402.7 \mathrm{a}-\mathrm{d}$ & $22.40 \mathrm{bc}$ & $270.9 \mathrm{f}$ & $109.6 \mathrm{~d}$ & $21.64 \mathrm{abc}$ & $3.023 \mathrm{c}$ & $5.41 \mathrm{bc}$ & 35.83 \\
$\mathrm{~T}_{4}$ & $293.4 \mathrm{~cd}$ & $24.33 \mathrm{a}$ & $293.0 \mathrm{c}$ & $109.9 \mathrm{~d}$ & $21.73 \mathrm{abc}$ & $2.977 \mathrm{c}$ & $4.960 \mathrm{c}$ & 37.30 \\
$\mathrm{~T}_{5}$ & $493.3 \mathrm{ab}$ & $21.80 \mathrm{c}$ & $262.8 \mathrm{~g}$ & $67.07 \mathrm{~g}$ & $19.07 \mathrm{c}$ & $4.81 \mathrm{a}$ & $6.86 \mathrm{ab}$ & 41.33 \\
$\mathrm{~T}_{6}$ & $421.2 \mathrm{abc}$ & $22.20 \mathrm{bc}$ & $280.8 \mathrm{e}$ & $73.47 \mathrm{f}$ & $19.88 \mathrm{c}$ & $4.39 \mathrm{ab}$ & $5.46 \mathrm{bc}$ & 44.23 \\
$\mathrm{~T}_{7}$ & $333.3 \mathrm{bcd}$ & $22.73 \mathrm{abc}$ & $287.9 \mathrm{~d}$ & $116.9 \mathrm{c}$ & $21.0 \mathrm{bc}$ & $3.75 \mathrm{abc}$ & $5.37 \mathrm{bc}$ & 41.12 \\
$\mathrm{~T}_{8}$ & $252.8 \mathrm{~cd}$ & $23 \mathrm{abc}$ & $297.1 \mathrm{~b}$ & $182.2 \mathrm{a}$ & $23.95 \mathrm{a}$ & $3.27 \mathrm{bc}$ & $4.86 \mathrm{c}$ & 40.45 \\
$\mathrm{~T}_{9}$ & $496 \mathrm{ab}$ & $21.87 \mathrm{bc}$ & $251.7 \mathrm{i}$ & $74.13 \mathrm{f}$ & $20.52 \mathrm{bc}$ & $4.27 \mathrm{ab}$ & $6.37 \mathrm{abc}$ & 40.18 \\
$\mathrm{~T}_{10}$ & $375.2 \mathrm{a}-\mathrm{d}$ & $22.60 \mathrm{abc}$ & $257.6 \mathrm{~h}$ & $76.60 \mathrm{f}$ & $20.86 \mathrm{bc}$ & $3.69 \mathrm{abc}$ & $6.35 \mathrm{abc}$ & 36.67 \\
$\mathrm{~T}_{11}$ & $320 \mathrm{bcd}$ & $23.67 \mathrm{ab}$ & $298.4 \mathrm{~b}$ & $111.7 \mathrm{~d}$ & $21.12 \mathrm{bc}$ & $3.24 \mathrm{bc}$ & $5.66 \mathrm{bc}$ & 36.36 \\
$\mathrm{~T}_{12}$ & $233.6 \mathrm{~d}$ & $22.87 \mathrm{abc}$ & $332.8 \mathrm{a}$ & $164.4 \mathrm{~b}$ & $22.64 \mathrm{ab}$ & $2.98 \mathrm{c}$ & $4.99 \mathrm{c}$ & 37.11 \\
\hline Level of & 0.05 & 0.01 & 0.01 & 0.01 & 0.01 & 0.05 & 0.05 & $\mathrm{NS}$ \\
significance & & & & & & & & \\
$\mathrm{CV}(\%)$ & 24.99 & 3.05 & 0.40 & 1.84 & 4.91 & 16.75 & 14.17 & 12.96 \\
\hline
\end{tabular}

Figures bearing letter(s) in common do not differ significantly, whereas figures with dissimilar letter(s) differ significantly.

\section{Single row:}

$\mathrm{T}_{1}=25 \mathrm{~cm} \times 10 \mathrm{~cm}\left(40\right.$ hills $\left.\mathrm{m}^{-2}\right)$

$\mathrm{T}_{2}=25 \mathrm{~cm} \times 15 \mathrm{~cm}(27$ hills

$\mathrm{T}_{3}=25 \mathrm{~cm} \times 20 \mathrm{~cm}\left(20\right.$ hills $\left.\mathrm{m}^{-2}\right)$

$\mathrm{T}_{4}=25 \mathrm{~cm} \times 25 \mathrm{~cm}$ (16 hills $\left.\mathrm{m}^{-2}\right)$

\author{
Paired row: \\ $\mathrm{T}_{5}=(35 \mathrm{~cm}+15 \mathrm{~cm}) \times 10 \mathrm{~cm}\left(40\right.$ hills $\left.\mathrm{m}^{-2}\right)$ \\ $\mathrm{T}_{6}=(35 \mathrm{~cm}+15 \mathrm{~cm}) \times 15 \mathrm{~cm}\left(27\right.$ hills $\left.\mathrm{m}^{-2}\right)$ \\ $\mathrm{T}_{7}=(35 \mathrm{~cm}+15 \mathrm{~cm}) \times 20 \mathrm{~cm}\left(20\right.$ hills $\left.\mathrm{m}^{-2}\right)$ \\ $\mathrm{T}_{8}=(35 \mathrm{~cm}+15 \mathrm{~cm}) \times 25 \mathrm{~cm}\left(16\right.$ hills $\left.\mathrm{m}^{-2}\right)$ \\ $\mathrm{T}_{9}=(30 \mathrm{~cm}+20 \mathrm{~cm}) \times 10 \mathrm{~cm}\left(40\right.$ hills $\left.\mathrm{m}^{-2}\right)$ \\ $\mathrm{T}_{10}=(30 \mathrm{~cm}+20 \mathrm{~cm}) \times 15 \mathrm{~cm}\left(27\right.$ hills $\left.\mathrm{m}^{-2}\right)$ \\ $\mathrm{T}_{11}=(30 \mathrm{~cm}+20 \mathrm{~cm}) \times 20 \mathrm{~cm}\left(20\right.$ hills $\left.\mathrm{m}^{-2}\right)$ \\ $\mathrm{T}_{12}=(30 \mathrm{~cm}+20 \mathrm{~cm}) \times 25 \mathrm{~cm}\left(16\right.$ hills $\left.\mathrm{m}^{-2}\right)$
}

Paired row had more grain on panicle than single row. 16 hills $\mathrm{m}^{-2}$ had more grains than 40 hills $\mathrm{m}^{-2}$ which may be attributed to the negative relationship between grain number and population density. The highest grain number panicle ${ }^{-1}(332.8)$ was found in paired row at a spacing of (30 $\mathrm{cm}+20 \mathrm{~cm}) \quad 25 \mathrm{~cm}$ and the lowest (225.1) was found in single row planting at a spacing of 25 $\mathrm{cm} \times 10 \mathrm{~cm}$ (Table 1). The reasons might be due to that competition for growth resources was more in closer spacing, at the same time assimilate production as well as translocation was also poor in over crowded stands (Zadeh and Mirlohi, 1998).

Sterile spikelets panicle $e^{-1}$ was higher in less planting density treatments. Best result was found in paired row planting and 16 hills $\mathrm{m}^{-2}$ had significantly more sterile spikelets than 40 hills $\mathrm{m}^{-2}$. Higher (182.2) sterile spikelets panicle $e^{-1}$ was found in paired row planting at a spacing of $(35 \mathrm{~cm}$ $+15 \mathrm{~cm}) \times 25 \mathrm{~cm}$ and the lowest (67.07) was found in also paired row planting at a spacing of $(35 \mathrm{~cm}+15 \mathrm{~cm}) \times 10 \mathrm{~cm}$.

Thousand grain weight decreased with decreasing spacing which may be attributed to the greater competition due to higher population density as the consequence of decreased spacing (Shah et al., 1996, Ang et al., 2002, Wang et al., 2002). The highest grain weight (23.95 g) was found 
Mahmud et al.

in paired row planting at a spacing of $(35 \mathrm{~cm}+15 \mathrm{~cm}) \times 25 \mathrm{~cm}$ and the lowest grain weight (19.07) was also found in paired row at a spacing of $(35 \mathrm{~cm}+15 \mathrm{~cm}) \times 10 \mathrm{~cm}$.

Paired row performed better than single row showing higher seed yields and 40 hills $\mathrm{m}^{-2}$ also performed better than 16 hills $\mathrm{m}^{-2}$. The highest grain yield $\left(4.81 \mathrm{t} \mathrm{ha}^{-1}\right)$ was recorded (Table 1$)$ in paired row at a spacing of $(35 \mathrm{~cm}+15 \mathrm{~cm}) \times 10 \mathrm{~cm}$ and lowest grain yield (2.97) was in single row planting at a spacing of $25 \mathrm{~cm} \times 25 \mathrm{~cm}$. The lowest yield of this treatment might be attributed to its lower number of tillers $\mathrm{m}^{-2}$, panicles $\mathrm{m}^{-2}$ (Table 1). Assimilate translocation towards grains was probably poorest in this treatment as compared to others. It was also evident from earlier reports (BRRI, 1992) that closer spacing gives more yield than wider spacing (Gupta and Sharma,1990; Mannan et al., 1991).

Straw yield increased with increasing planting density which is obvious as increased planting density increases straw (Islam et al.,1994). The highest straw yield $\left(7.29 \mathrm{t} \mathrm{ha}^{-1}\right)$ was recorded in single row at a spacing of $25 \mathrm{~cm} \times 10 \mathrm{~cm}$ and also found highest in spacing $(35 \mathrm{~cm}+15 \mathrm{~cm}) \times$ $10 \mathrm{~cm},(30 \mathrm{~cm}+20 \mathrm{~cm}) \times 10 \mathrm{~cm},(30 \mathrm{~cm}+20 \mathrm{~cm}) \times 15 \mathrm{~cm}$, respectively. The lowest was recorded in paired row at a spacing of $(35 \mathrm{~cm}+15 \mathrm{~cm}) \times 25 \mathrm{~cm}$.

Harvest index did not follow any regular trend and no significant difference was not obtained due to variation in planting densities. But roughly it could be assumed that increasing population density decreased harvest index. The highest harvest index (44.23) was found in paired row at a spacing of $(35 \mathrm{~cm}+15 \mathrm{~cm}) \times 15 \mathrm{~cm}$ having 27 hills $\mathrm{m}^{-2}$ and the lowest harvest index (35.83) was found in single at a spacing of $25 \mathrm{~cm} \times 20 \mathrm{~cm}$ having 20 hills $\mathrm{m}^{-2}$.

From the findings of the present study it might be concluded that paired row planting of $(35 \mathrm{~cm}$ $+15 \mathrm{~cm}) \times 10 \mathrm{~cm}$ spacing $\left(40\right.$ hills $\mathrm{m}^{-2}$ ) found the best planting pattern of rice variety BRRI dhan28 rice in terms of producing the highest grain yield $\left(4.81 \mathrm{t} \mathrm{ha}^{-1}\right)$.

\section{References}

AIS. 2014. 'Krishi Diary', Agricultural Information Service. Khamarbari, Farmgate, Dhaka, Bangladesh.

Akita, K. 1982. Studies on competition and compensation of crop plants: Effects of spacing on growth organs of rice. Sci. Res., Fac. Agric., Kobe Univ., Japan. 15(1): 11-16.

Ang, S., X. Wang, Z. Xing and S. Xie 2002. Assessment of using SRI with super hybrid rice variety Liangyoupei 9. In: Assessments of the System of Rice Intensification. Proc. Intl. Conf. Sanya, China. April 1-4, 2002. pp.112-113.

Anonymous. 1992. BRRI Annual Report for 1991. Bangladesh Rice Res. Inst., Joydebpur, Bangladesh.

Balasubramaniyan, P. and S. Palaniappan. 1991. Effect of high density population and fertilizer rate of growth and yield of lowland rice (Oryza sativa). Indian J. Agron. 36 (supplement): 10-13 [Rice Abst., 16(1): 16, 1993].

BRRI (Bangladesh Rice Research Institute). 1990. Adhunik Dhaner Chash (In Bangla) $6^{\text {th }}$ Edn. Bangladesh Rice Res. Inst. Joydebpur, Gazipur. pp.26-27.

BRRI (Bangladesh Rice Research Institute). 1992 Annual Report for 1990. Bangladesh Rice Res. Inst. Joydebpur, Gazipur, Bangladesh. pp.11-13.

BRRI (Bangladesh Rice Research Institute). 1995. Adhunik Dhaner Chash (In Bangla) $7^{\text {th }}$ (revised) Edn. Bangladesh Rice Res. Inst. Joydebpur, Gazipur. pp.3-34. 
Planting Density effects on Boro Rice

Counce, P. A., K. A. K. Moldenhauer, and D. B. Marx. 1989. Rice yield and plant yield variability response to equidistant spacing. Crop Sci. 29: 175-179.

Duncan, W. G. 1986. Planting patterns and soybean yield. Crop Sci. 26: 584-588.

Gomez, K. A. and A. A. Gomez, 1984. Statistical Procedure for Agricultural Research. Intl. Rice Res. Inst. John Willey and Sons. New York. p.340.

Gupta, A. K. and R. S. Sharma. 1990. Effect of plant spacing and fertility level on grain yield of early medium indica rice (Oryza sativa L.). Indian J. Agron. 36 (Supplement): 223-225.

Hassan, M. 1991. Competitive behaviour of four rice (Oryza sativa L.) genotypes grown in mixture. An unpublished M. Sc. (Ag.) Thesis submitted to Bangladesh Agril. Univ., Mymensingh. p.66.

Islam, A. J. M. A. 1986. Review of Agronomic research on rice and its further strategy. Adv. Agron. Res. Bangladesh. 1: 1-19.

Islam, M. S., M. A. R. Sarkar, M. S. Rahman, A. M. Musa and S. C. Dhan. 1994. Effect of plant population density on transplant aus rice under tidally flooded conditions. Bangladesh $\mathrm{J}$. Agril. Sci., 21(2): 349-353

Jahan, M. S. 1988. Allometry, Resource Allocation and Yield in Mugbean: Effect of population density and planting configuration. M.S Thesis in Agronomy. Institute of Postgraduate Studies in Agriculture, Gazipur. pp.22-29.

Karim, M. A., A. Ali. L. Ali, S. Ali, A. Mahmood., A. Majid and T. A. Akthar. 1992. Effect of plant density on rice grain quality. Intl. Rice Res. Newsl. 17(6): 12. [Rice Abst. 1993. 16(3):168]

Liou, T. M. 1987. Effect of spacing and fertilizer levels on changes of ear type in rice. J. Agric. Assoc. China., 140: 1-10.

Mannan, M. A., M. B. Rahman., A. A. Chowdhury and S. B. Siddique. 1991. Yield of modern irrigated rice varieties under different population dynamics in Bangladesh. Bangladesh Rice J. 2(1-2): 59-62.

Miah, M. H., M. A. Karim, M. S. Rahman and M. S. Islam. 1990. Performance of Nizersail mutants under row spacings. Bangladesh J. Training Dev. 3(2): 31-34.

Miah, M. and A. Hamid. 1999. Impact of agricultural research in Bangladesh (Crops and Forestry). Paper presented at workshop on 'Transfer of Agricultural Technologies' held at Bangladesh Agril. Res. Council, Dhaka, June 28-29.

Miller, B. C., J. E. Hill and S. R. Roberts. 1991. Plant population effects on growth and yield in water seeded rice. Agon. J. 83(2): 291-297.

Rahman, M. H. 1997. Influence of irrigation and planting density on growth and seed yield in edible podded pea. M.S Thesis in Agronomy. Institute of Postgraduate Studies in Agriculture, Gazipur. pp.20-25.

Roshid, A. 1998. Population density and source-sink manipulation effect of sesame. M.S Thesis in Agronomy. Institute of Postgraduate Studies in Agriculture, Gazipur. pp.19-24.

Shah, N. H., M. K. Kuhshu, B. A. Khamday and A. S. Bali. 1991. Effect of spacing and seedling hill ${ }^{-1}$ on transplanted rice under late sown condition. Indian J. Agron. 36(2): 274-275.

Shah, A. L., A. H. Khan and A. R. Gomosta. 1996. Effect of some cultural practices on the yield components and yield of BR 3 rice in dry season. Bangladesh Rice J. 7(1 and 2): 81-84. 
Mahmud et al.

Talukder, M. A. M. 1998. Planting density effects on productivity of old and modern varieties of rice in relation to canopy structure and light interception. Ph.D Dissertation. Bangabandhu Sheikh Mujibur Rahman Agril. Univ., Gazipur. Bangladesh. pp.39-43.

Wang, S., W. Cao, D. Jiang, T. Dai and Y. Zbu. 2002. Physiological characteristics and high yield techniques with SRI Rice. In: Assessments of the System of Rice Intensification. Proc. Intl. Conf. Sanya, China. April 1-4, 2002. pp.117-121.

Willey, R. B. and S. B. Heath. 1969. The quantitative relationship between plant populations and crop yield. Adv. Agron. 21: 281-321.

Zaman, S. M. H. 1996. Current status and prospects for rainfed food grain production in Bangladesh. Bangladesh Rice Res. Inst. Pub. No.75. p.56.

Zadeh, M. R. and A. Mirlohi. 1998. Plant population and planting pattern effects on yield and yield components of rice (Oryza sativa L.) in Isfahan. J. Agril. Sci. Nat. Resour. 2(2): 61-71. 